\title{
Web-Based Management of Goods Demand Applications In The Nusantara Fraction of The Office Of The DPRD North Sumatra
}

\author{
Fitriani $^{*}$, Suhardi* \\ Computer Science Study Program, North Sumatra State Islamic University, Medan
}

\begin{tabular}{l}
\hline \hline A R T I C L E I N F O \\
\hline Article history: \\
Received Oct 1, 2021 \\
Revised Dec 10, 2021 \\
Accepted Jan 25, 2022 \\
Available online Jan 31,2022 \\
\hline
\end{tabular}

Keywords:

application

php

mySQL

\begin{abstract}
A B S T R A C T (10 PT)
The Nusantara Faction is a combination of several parties, namely the United Development Party (PPP), Perindo Party and the National Awakening Party (PKB) which are in charge of running the government. The Nusantara Faction is in the government office of the North Sumatra Province Regional House of Representatives (DPRD-SU). In order to carry out their duties smoothly, the Nusantara Faction requires work goods and equipment. The system for managing demand for goods in the Nusantara Faction is still carried out conventionally, namely data for managing demand for goods still uses paper. The current system still has a shortage of inputting data for managing demand for goods, causing quite a long time. The goal to be achieved is to make it easier for staff who work in the Nusantara Faction in carrying out and managing requests for goods in the Nusantara Faction can be run online. So it is necessary to have a web-based goods demand management application which is expected to be able to overcome the problems that occur in the Nusantara Faction. With this application, it can make it easier to input data for managing demand for goods and provide solutions to overcome problems during the process of inputting data for managing demand for goods.
\end{abstract}

(C) 2022 The Author(s). Published by AIRA This is an open access article under the CC BY-SA license (http://creativecommons.org/licenses/by-sa/4.0/).

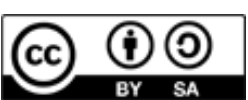

\section{Corresponding Author:}

Fitriani,

Department of Computer Science, North Sumatra State Islamic University, Medan

Email: fitrianilubis9912@gmail.com

\section{INTRODUCTION}

In this increasingly modern era, the sophistication of information technology is very important for both individuals and groups. Information technology is an inseparable part of office activities, where information technology can facilitate activities in offices, especially in the field of storing important office data which used to only use storage media in physical form (paper), but along with the development of storage media times. changed into a more practical form, namely in digital form.

Office activities are identical to the various equipment or needs needed. Office equipment is objects that are used up in day to day operations by administrative employees[1]. If there is no management of the office equipment and the distribution will be disproportionate. At this time the process of requesting goods in the Nusantara Faction still uses paper, data collection on demand for goods is still not optimal, because the process still has to be inputted one by one into Microsoft Excel based on the demand for goods.Based on the above, the authors take the problems that exist in the Nusantara Faction regarding the process of managing and collecting data on demand for goods from a paper system into a computerized system, it is hoped that this new system can facilitate the demand and procurement of goods in the Nusantara Faction.

In making a computerized demand management system for goods, the authors use PHP and MySQL. Where PHP stands for Hypertext Preprocessor, which is a programming language that is widely used for handling, creating and developing a website and is usually used in conjunction with HTML[2]. And MySQL (MyStructure Query Language ) is a database that is quite well known because almost most web -based applications such as WordPress, are equipped with MySQL. In addition, MySQL is used in various versions, including the free version[3]. The Web or the World Wide Web (www) are web pages that can be connected to each other which form an ocean of information wilderness [4]. XAMPP is free software that supports multiple operating systems, which is a compilation of several programs. XAMPP functions as a stand alone server[5]. HTML stands for Hypertext Markup Language. Called Hypertext because in HTML a plain text can function differently, we can make it a link that can move from one page to another by clicking on the text[6]. Codeigniter is a PHP framework based on MVC (Model View Controller)[7]. 


\section{RESEARCH METHOD}

2.1 Software Development Method

Software development is a framework for building high quality software. In developing software adequately it must be defined in advance [8]. In this study, the research method that the author uses is the waterfall method . The Waterfall method or what is often called the waterfall method is often called the Classic Life Cycle, where it describes a systematic and sequential approach to software development, starting with the specification of user requirements and then continuing through the stages.

In the process, the stages carried out are completed one by one first then move on to the next stage after it is fully completed. For this reason, the waterfall method is recursive in that each phase can be repeated endlessly until it is perfected starting from problem identification, system design, implementation, testing, testing and maintenance. If the trial stage is not in accordance with the results, then the research stage will be evaluated starting with problem identification.

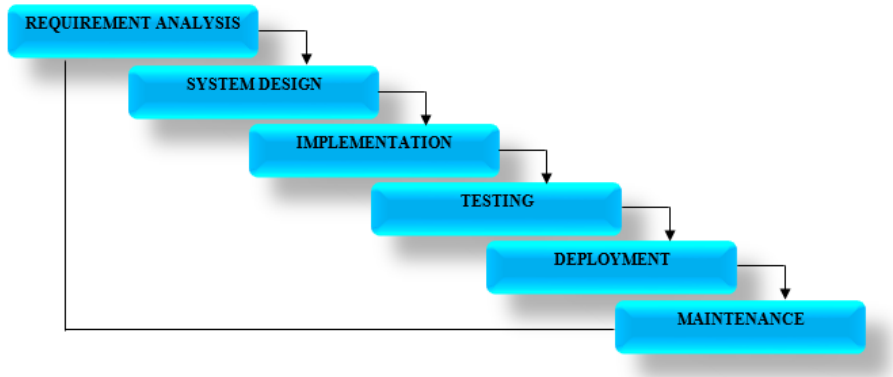

Figure 1. Waterfall Model

The stages of implementation in the waterfall model are as follows:

1. System requirements are the first step to determine the need for applications to be made including system design, appearance and interface that must be adapted to needs.

2. System design is the stage of how the application is presented in each form in the form of a later application display that will be operated by the user .

3. Implementation is the stage of making applications or coding in accordance with system requirements and the system design is made.

4. Testing is the stage where the application that has completed the system requirements and system design is then inputted data to test the running of the application.

5. The trial is the stage of completing the overall testing of the application whether it is in accordance with the needs of the application.

6. Maintenance is the stage of maintaining the system as a whole, with maintenance if there is a change in terms of both software and hardware[9].

\subsection{System Design}

The design of this system is the stage of system design that will be formed which can be in the form of describing the processes of an element of a component, this design process is an early stage of designing a web-based goods demand management application in the Nusantara Fraction. The design is made to make the application of web-based management of the demand for goods starts from making usecase diagram.

Usecase is a narrative description in the form of a framework of the dialogue that occurs between the primary system and the secondary system. Use case describes an interaction between one or more actors and the information system that will be created. Use cases are used to find out what functions are in an information system and who has the right to use those functions. The main purpose of use case modeling is to decide and describe the functional requirements of the system and also provide a basis for conducting system testing and system verification [10]. The usecase diagram for design management applications demand web-based goods in the archipelago fraction are as follows:

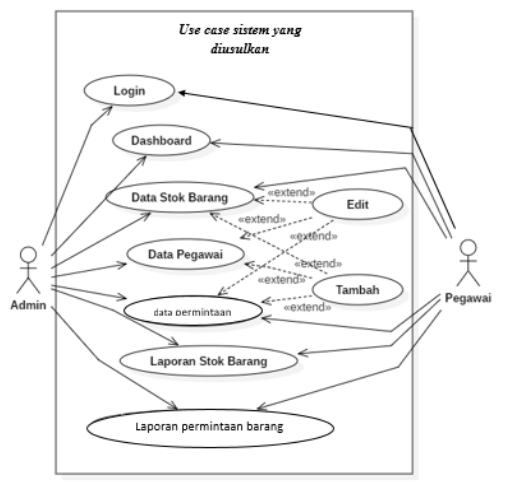


Figure 2. Use Case Diagram

In Figure 1 the use case diagram, there are two actors involved in the system, namely admin/administration and employees. The description of the actor with the use case is that the admin/administration is an actor who has the right to login, open the dashboard, view stock data, manage employee data, approve request data, view inventory reports, and view goods request reports. Meanwhile, employees are actors who have the right to $\log$ in, open the dashboard, view stock data, make requests for goods, view inventory reports and view reports on demand for goods.

2.3 Database Design

To create an information system for managing demand for goods, the database created is as follows:

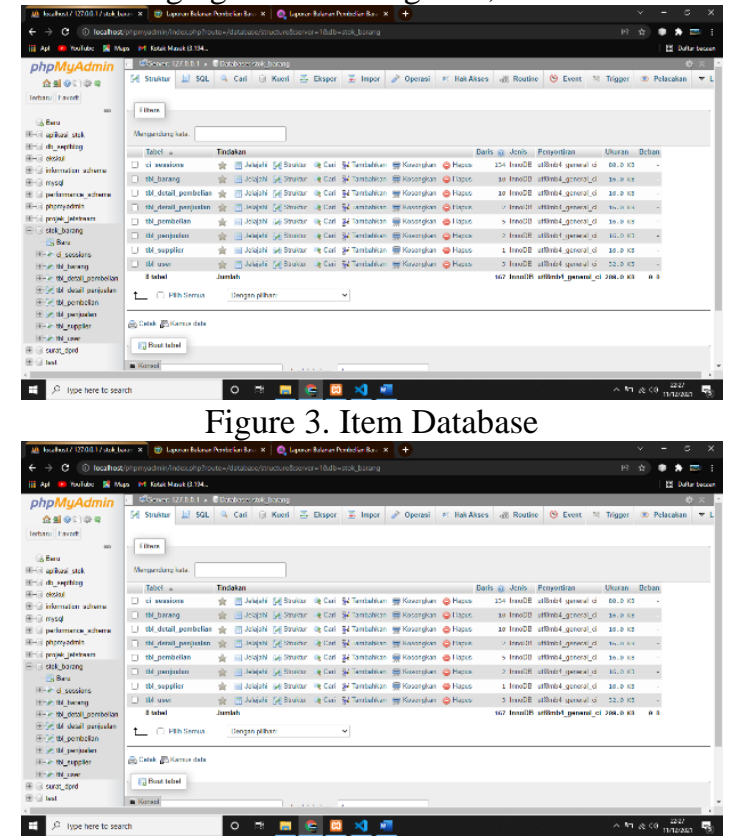

Figure 4. Database Query Table

\section{RESULTS AND DISCUSSION}

After doing the proposed design is complete, then the next thing to do is to design the interface or system display. The appearance of the web-based goods demand management design in the Nusantara Fraction at the North Sumatra DPRD Office is as follows:

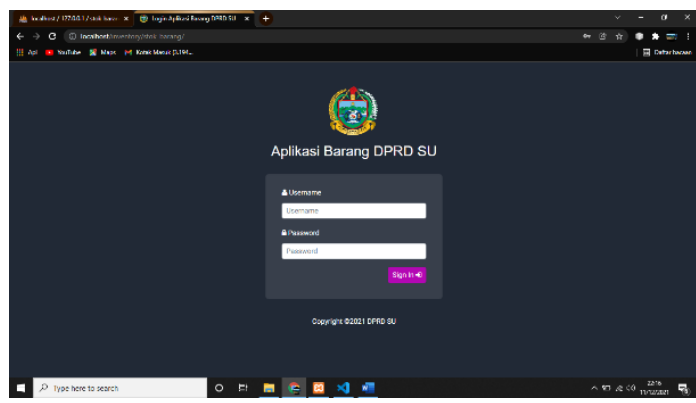

Figure 5. Login Page Display

On this login page, those who can access it are admin/administration and staff/employees at the Nusantara Faction. How to login is to enter the username and password that has been determined. After successful login, you will see the dashboard display as shown below

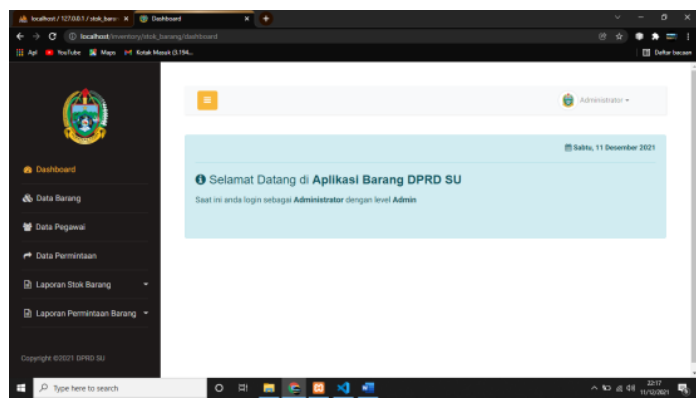

Figure 6. Dashboard Display 
On the dashboard page , menus will appear as listed above, namely item data, employee data, demand data, stock reports and item demand reports.

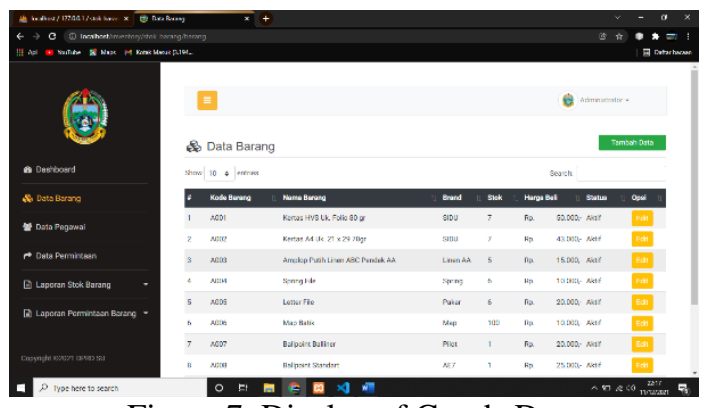

Figure 7. Display of Goods Data

On the item data page, you will see the item code display, item name, brand, purchase price, status and options.

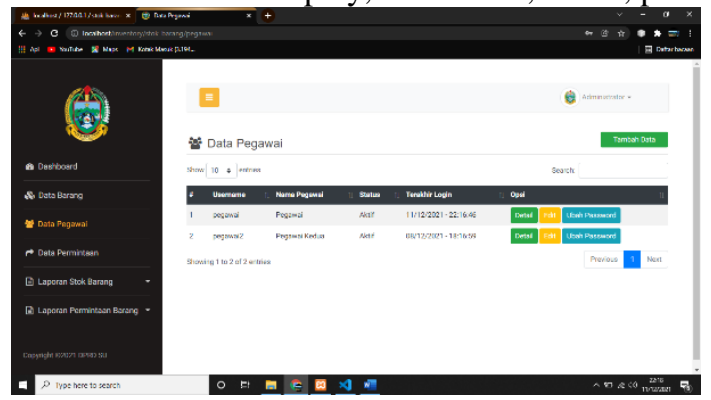

Figure 8. Display of Employee Data

In the employee data display above, there is a username, employee name, status, last login and options.

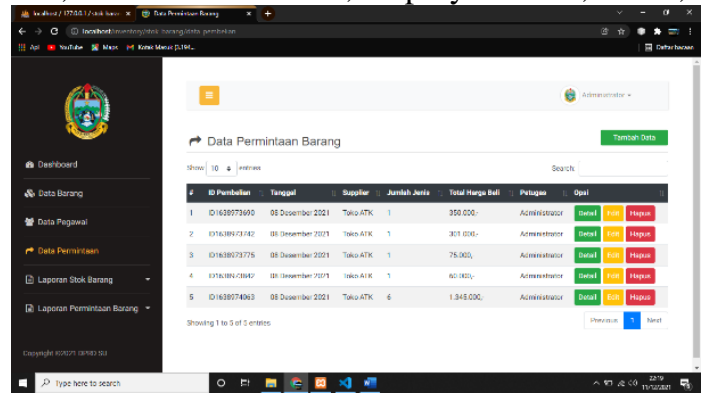

Figure 9. Display of Goods Request

In the goods request view above, in this view you can manage data on demand for goods, starting from viewing the details of the request for goods, editing the request for goods and deleting the request for goods.

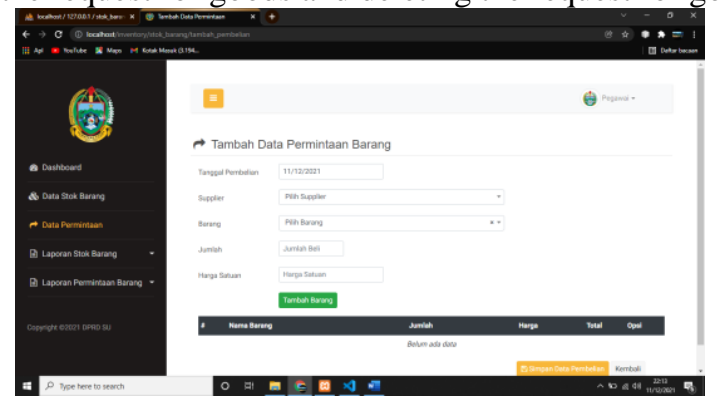

Figure 10. Add Item Request

In the display of added demand for goods above, it can be managed to increase the demand for goods and the amount needed.

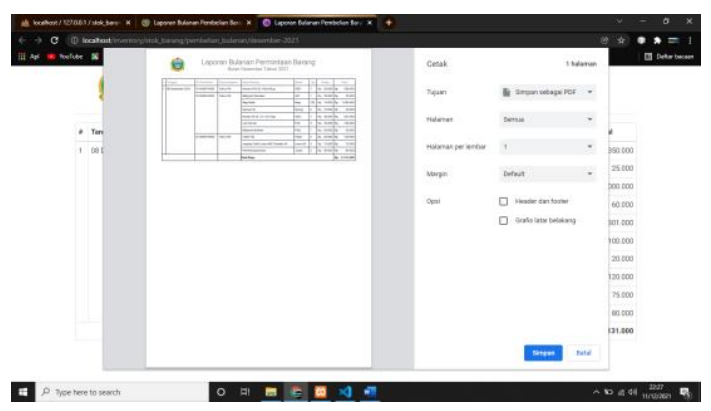


Figure 11. Print Request for Goods

After making a request for goods, it can be printed as shown above.

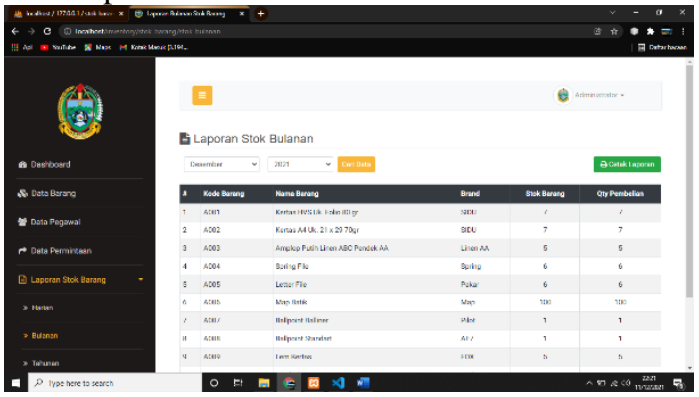

Figure 12. Monthly Stock Display

In the monthly stock display above, it can be seen clearly what items are available in stock. And if the goods are out of stock, you can request more goods according to work needs.

\section{CONCLUSION}

After doing this research, it can be concluded that the research method used is the waterfall method, which is a method that goes through stages starting from requirements analysis, system design, implementation, testing, deployment, and maintenance. This web -based goods demand management application was created using the PHP programming language, MySQL database, the CodeIgniter framework and the Visual Code Studio text editor .

\section{REFERENCES}

[1] Rusdiana dan Qiqi Yulianti Zaqiah, 2020, Manajemen Perkantoran Modern, Penerbit Insan Komunika, Bandung.

[2] Jubilee Enterprise, 2018, Database Programming with Python and MySQL, PT Elex Media Komputindo, Jakarta.

[3] Hening Widi Oetomo and Pontjo Bambang Mahargiono, 2020, PHP and MySQL Applications in the Management Sector, Ed.1, CV Andi Offset, Yogyakarta.

[4] Rintho Rante Rerung, 2018, Basic WEB Programming, CV Budi Utama, Yogyakarta.

[5] Bay Haqi, 2019, Aplikasi SPK Pemilihan Dosen Terbaik Metode Simple Additive Weighting (SAW) Dengan Java, Deepublish Publisher, Yogyakarta.

[6] Rintho Rante Berung, 2018, Pemrograman Web Dasar, CV Budi Utama, Yogyakarta.

[7] Muhammad Nurkamal Fauzan dan Rahmi Rova, 2019, Tutorial Sistem Informasi Approval Berbasis WEB Menggunakan Framework Codeigniter Dengan Notifikasi Email, Kreatif Industri Nusantara. Bandung.

[8] Dedy Rahman Prehanto, 2020, Concept of Information Systems, Scopindo Media Pustaka. Surabaya

[9] Solehatin dan Chairul Anam, 2020, E-Deteksi Kematangan Buah Jeruk Banyuwangi Menggunakan Metode KNN Berbasis Android, Deepublish Publisher, Yogyakarta.

[10] Ira Puspita Sari, 2021, Android-Based Forest Fire Monitoring System, Gracias Kreatif, Ponorogo. 